Volume 6 Nomor 1, Februari 2021, halaman 33 - 54.

\title{
Analisis Kesalahan Dalam Menyelesaikan Masalah Himpunan Siswa SMP Kelas VII Ditinjau Dari Gender
}

\section{Analysis Of Errors In Resolving Set Problems Of Junior Junior High School Student Class VII Reviewed From Gender}

\author{
Indra Zulfayanto ${ }^{1}$, Sinta Lestari' ${ }^{2}$, Tsamrotul Ilmiah ${ }^{3}$, Mustangin ${ }^{4}$ \\ 1.2.3.4 Universitas Islam Malang, Jl. Mayjen Haryono No.193, Dinoyo, Kec. Lowokwaru, \\ Kota Malang, Jawa Timur 65144 \\ Email:21701072013@unisma.ac.id,21701072029@unisma.ac.id, \\ 21701072024@unisma.ac.id, mustangin@unisma.ac.id
}

\begin{abstract}
ABSTRAK
Penelitian ini bertujuan untuk mendeskripsikan kesalahan dalam menyelesaikan masalah himpunan siswa perempuan dan laki-laki. Manfaat dari penelitian inidapat menambah dan memberikan pengetahuan tambahan dalam ilmu pendidikan dan untuk menyelesaikan masalah matematika, khususnya masalah himpunan. Jenis penelitian ini yaitu deskriptif kualitatif. Penelitian ini dilakukan di SMPN 1 Moyo Utara. Subjek dalam penelitian ini adalah siswa kelas VII yang berjumlah 10 siswa. Teknik pengumpulan data yang digunakan adalah tes dan wawancara. Uji keabsahan data dilakukan menggunakan metode triangulasi yaitu dengan membandingkan data hasil tes dandata hasil wawancara dengan subjek. Analisi data dalam penelitian ini dilakukan dengan reduksi data, penyajian data, veririfikasi data dan penarikan kesimpulan. Dasar analisis data dalam penelitian ini menggunakan indikator kesalahan menurut Newman. Dari data penelitian diperoleh 5 kesalahan baik dari siswa laki-laki maupun perempuan, dengan persentase kesalahan siswa laki-laki yaitu:Reading errorsebesar70\%, Comprehension error sebesar 80\%, Transformation error sebesar 80\%, Process skill error sebesar 80\%, dan Encoding error sebesar $80 \%$. Sedangkan persentase kesalahan dari siswa perempuan yaitu: kesalahan Reading error sebesar 5\%,Comprehension error sebesar 95\%, Transformation error sebesar 95\%, Process skill error sebesar 95\%, danEncoding errorsebesar95\%. Hasil penelitian menunjukkan bahwa tidak ada perbedaan yang begitu mencolok antara kesalahan siswa laki-laki dan perempuan dalam menyelesaikan masalah himpunan kelas VII di SMPN 1 Moyo Utara.
\end{abstract}

Kata kunci : kesalahan, himpunan, gender.

\begin{abstract}
This study aims to describe the mistakes of male and female students in solving set problems. The benefit of this research is that it can add and provide additional knowledge in education to solve math problems, especially on set problems. This type of research is descriptive qualitative. This research was conducted at SMPN 1 Moyo Utara. The subjects of this study were 10 grade students. The data collection techniques used were tests and interviews. The data validity test was conducted using triangulation methods, namely by comparing the test data with the results of interviews with the subject. Data analysis in this study was carried out by data reduction, data presentation, data verification and conclusion drawing. The basis of data analysis in this study uses an error indicator according to Newman. From the research data, it was obtained 5 errors from both male
\end{abstract}


and female students, with the percentage of male students error is: Reading error by $70 \%$, Comprehension error by $80 \%$, Transformation error by $80 \%$, Process skill error by $80 \%$, and Encoding error by $80 \%$. While the percentage of female students error is: Reading error is 5\%, Comprehension error is 95\%, Transformation error is 95\%, Process skill error is $95 \%$, and Encoding error is $95 \%$. The results showed that there was no significant difference between the errors of male and female students in solving class VII association problems at SMPN 1 Moyo Utara.

Keywords: error, set, gender.

How to Cite: Zulfayanto, I., Lestari, S., Ilmiah, T., Mustangin, M. (2021). Analisis Kesalahan Dalam Menyelesaikan Masalah Himpunan Siswa SMP Kelas VII Ditinjau Dari Gender. Mathline: Jurnal Matematika dan Pendidikan Matematika, Vol. 6 No. 1, 33 - 54.

DOI: https://doi.org/10.31943/mathline.v6i1.172

\section{PENDAHULUAN}

Matematika merupakan ilmu dasar dengan bidang penelitian yang penting, Matematika merupakan ilmu dasar dari perkembangan ilmu pengetahuan dan teknologi, oleh karena itu matematika perlu dipelajari mulai dari tingkat dasar hingga tingkat universitas (Munawaroh et al., 2018). Banyak orang yang beranggapan bahwa tolak ukur kepintaran seseorang dalam belajar adalah penguasaan dalam matematika. Akan tetapi pada kenyataannya banyak dari siswa yang merasakan bahwa belajar matematika merupakan sesuatu yang sangat membosankan. Matematika merupakan salah satu ilmu yang penting untuk dipelajari, karena matematika merupakan pilar utama dari ilmu pengetahuan.

Menurut (Wahyuni et al., 2019) Matematika juga merupakan ilmu penting yang harus ada dan dimiliki dalam dunia pendidikan, karena hampir segala sesuatu yang dilakukan dalam kehidupan sehari-hari pasti melibatkan perhitungan matematis, tidak peduli besar atau kecilnya. Perkembangan ilmu pengetahuan juga dipengaruhi oleh matematika. Bagaimana para profesor matematika menggunakan konsep yang ada untuk berpikir logis dan menata dengan rapi seuai dengan konsep yang ada (Kamariah, 2018). Hal ini berarti tidak mengherankan jika prestasi siswa dalam matematika menjadi petunjuk kecerdasan siswa tersebut.

Pendidikan merupakan kebutuhan yang harus dipenuhi dalam hidup. Pendidikan akan mempengaruhi cara berpikir orang dan membuat semua aspek kehidupan berkembang ke arah yang lebih baik (Suciati \& Wahyuni, 2018). Keberhasilan pendidikan bergantung pada perubahan dan reformasi berbagai komponen pendidikan. Unsur-unsur yang mempengaruhi penyelenggaraan pendidikan antara lain kurikulum, sarana prasarana, guru, 
siswa dan metode pengajaran yang sesuai (Ulifa \& Effendy, 2019). Guru dan siswa merupakan bagian penting dari penentu keberhasilan proses pembelajaran di kelas. Guru memiliki tanggung jawab untuk mengatur proses pembelajaran di kelas, sedangkan siswa memiliki kemampuan, motivasi dan kesiapan diri untuk mengikuti proses pembelajaran di kelas (Nur Aly et al., 2019). Saat ini, proses pembelajaran yang berpusat pada guru masih banyak diadopsi oleh guru di kelas. Pembelajaran semacam ini ternyata lebih menitikberatkan pada hasil daripada proses pembelajaran itu sendiri, sehingga pembelajaran terkesan monoton. Intinya tidak ada masalah dengan proses pembelajaran yang berpusat pada guru, hal ini sangat penting dalam penerapannya, guru tetap melibatkan siswa, sehingga mereka selalu dapat aktif dalam proses pembelajaran matematika (Mustangin et al., 2019).

Dalam pelaksanaan pembelajaran di kelas, guru masih banyak menggunakan pembelajaran biasa yaitu dalam pembelajaran masih menggunakan metode ceramah, sehingga prestasi belajar matematika rendah (Rahayu, 2016). Dari kemampuan siswa dalam menyelesaikan masalah matematika dapat dilihat bahwa prestasi belajar siswa mengalami peningkatan atau tidak. Namun, siswa membuat banyak kesalahan saat menyelesaikan soal matematika. Dengan memahami kesalahan yang dilakukan dalam menjawab soal matematika yang diberikan, maka prestasi akademik siswa dapat ditingkatkan. Kesalahan dalam menyelesaikan soal matematika tersebut perlu dianalisis untuk mengetahui kesalahan yang mana dan mengapa siswa melakukan kesalahan tersebut. Dengan menganalisis kesalahan tersebut dapat diperoleh bentuk dan alasan kesalahan siswa sehingga guru dapat memberikan berbagai bantuan kepada siswa (Sahriah, 2012).

Menurut Lipianto (Sumadiasa, 2014) Analisis kesalahan merupakan penyelidikan terhadap jenis-jenis kesalahan yang dilakukan siswa dalam menyelesaikan masalah matematika, dan dapat mengetahui faktor-faktor penyebab kesalahan tersebut. Berdasarkan penelitian yang dilakukan oleh Ruswati \& Senjawati di sebuah sekolah menengah pertama di Cimahi pada tahun 2015, siswa masih cenderung sering melakukan kesalahan dalam setiap indikator pemecahan masalah matematika, hal ini disebabkan ketidakmampuan siswa dalam mengidentifikasi masalah dan kurangnya akurasi dalam melakukan perhitungan (Timutius et al., 2018).

Dengan memberikan tes atau soal, kita dapat mengetahui kesalahan siswa dalam menjawab soal. Setelah tes atau soal diberikan kepada siswa, kita dapat mengetahui dan menganalisis letak kesalahan yang dilakukan siswa dalam menjawab soal yang diberikan. Setelah menemukan kesalahan tersebut, kenali kesalahan yang dilakukan oleh siswa agar 
dapat menemukan solusi untuk mengatasi kesalahan yang sering dilakukan siswa. Dalam menyelesaikan soal himpunan, siswa Indonesia masih banyak melakukan kesalahan yang disebabkan oleh banyak faktor. Salah satunya adalah pemahaman siswa yang kurang dalam mengonversi bentuk soal cerita ke dalam model matematika. Hal ini membuat siswa kesulitan untuk menyelesaikan soal yang diberikan. Terkait kesalahan dalam memecahkan soal, Newman mengembangkan model yang dikenal sebagai Newman Error Analysis yang terdiri dari lima kategori kesalahan yaitu membaca (reading), pemahaman (comprehension), transformasi (transformation), keterailan proses (process skill), dan jawaban akhir (encoding)

Keberhasilan siswa dalam menyelesaikan soal matematika adalah salah satu faktor tercapainya tujuan dalam pembelajaran matematika. Sehingga dengan menemukan solusi dari permasalahan yang dialami siswa dalam menyelesaikan soal-soal matematika maka tujuan dalam pembelajaran tersebut telah tercapai .

Dalam pembelajaran di sekolah tidak terlepas dari adanya komponen, baik itu siswa perempuan atau siswa laki-laki. Dengan kata lain, proses pembelajaran tidak terlepas dari gender (jenis kelamin). Gender merupakan suatu konsep budaya yang mengacu pada ciriciri yang membedakan laki-laki dari perempuan secara fisik, perilaku, spiritual dan sosial. Anak laki-laki dan perempuan memiliki kelebihan masing-masing dalam belajar matematika. Dalam hal ini, laki-laki lebih pandai dalam pernalaran logis (Aini, 2017).

Dalam keadaan sehari-hari kita dapat melihat bahwa sebagian besar siswa laki-laki dalam lingkungan bermainnya kebanyakan menghabiskan waktu luangnya diluar rumah sedangkan perempuan menghabiskan sebagian waktu luangnya di rumah. Perempuan yang kebanyakan menghabiskan waktu di rumah tentunya akan lebih banyak memiliki waktu luang untuk belajar dan mengulang materi yang telah dijelaskan disekolah. Perbedaan gender lain yang mempengaruhi proses belajar siswa laki-laki dan perempuan yaitu perempuan lebih memiliki pendengaran yang lebih teliti dan sensitif terhadap suara keras dibandingkan laki-laki.

Berdasarkan informasi yang didapatkan dan pengalaman guru di SMPN 1 Moyo Utara kesalahan siswa banyak terjadi dalam menyelesaikan soal-soal yang diberikan, salahsatunya adalah dalam memahami perintah soal yang diberikan oleh guru dalam pembelajaran.

Berikut adalah bukti kesalahan dalam memahami perintah soal. 


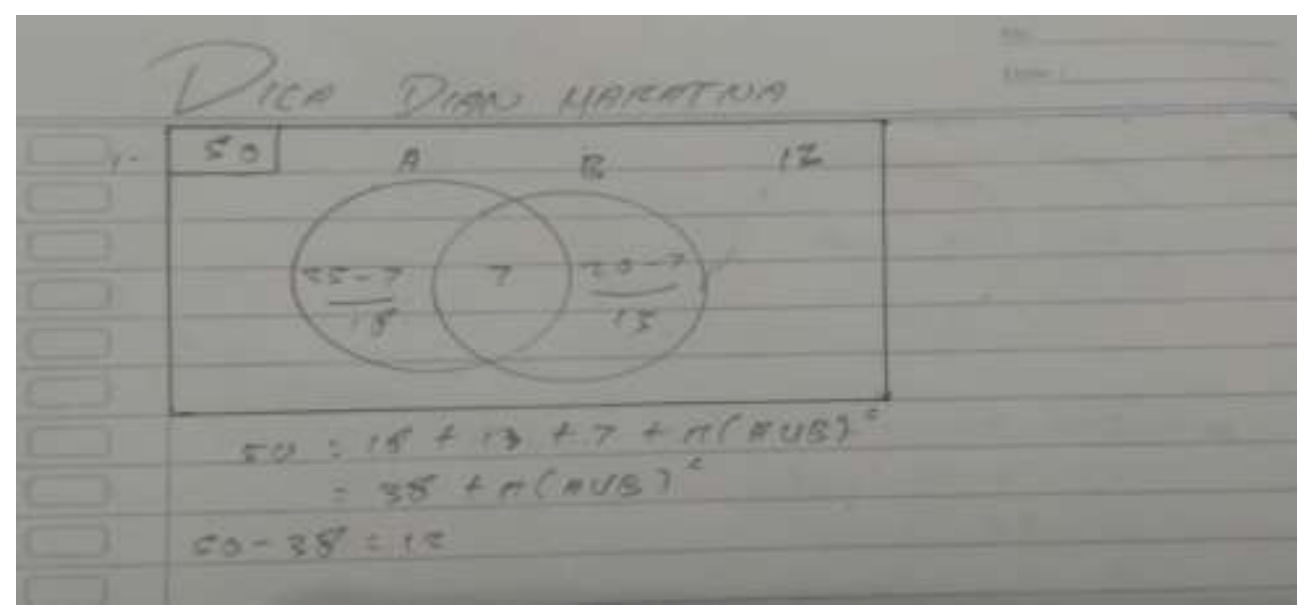

Gambar 1. Kesalahan dalam memahami perintah soal

Berdasarkan Gambar 1 di atas siswa tidak menuliskan informasi dan apa yang ditanyakan di dalam soal akan tetapi langsung pada proses pengerjaan hal ini dikarenakan siswa masih belum terbiasa untuk menuliskan apa yang diketahui dalam soal dan terfokus pada penyelesaian soal..

Selain kesalahan yang dilakukan tersebut tidak menutup kemungkinan bahwa masih terdapat kesalahan yang dilakukan oleh siswa yang menyebabkan rendahnya hasil belajar siswa dalam pembelajaran.

Berdasarkan pengamatan peneliti, materi himpunan menjadi fokus pembahasan dalam penelitian ini. Hal ini dikarenakan materi himpunan harus dikuasai siswa dikarenakan berhubungan erat dengan materi yang selanjutnya. Materi himpunan dapat diaplikasikan kedalam bidang ilmu lainnya seperti bidang ilmu biologi. Himpunan dapat digunakan dalam klasifikasi makhluk hidup dalam ilmu biologi.

Berdasarkan penjelasan di atas, maka tujuan utama penelitian ini adalah untuk: (1) mendeskripsikan kesalahan siswa dalam menyelesaikan masalah himpunan ditinjau dari gender siswa kelas VII, (2) mendeskripsikan kesalahan siswa perempuan dalam menyelesaikan masalah himpunan kelas VII, (3) mendeskripsikan kesalahan siswa laki-laki dalam menyelesaikan masalah himpunan kelas VII.

\section{METODE PENELITIAN}

Penelitian ini merupakan penelitian deskriptif kualitatif. Menurut Arikunto (Sudiono, 2017) menjelaskan bahwa penelitian deskriptif bertujuan untuk mengetahui situasi, kondisi atau hal lain yang disebutkan, dan hasilnya disajikan dalam bentuk laporan penelitian. Waktu dan tempat dilakukan pada bulan Desember 2020 di SMPN 1 Moyo 
Utara dengan subjek yaitu siswa kelas VII dengan jumlah siswa 10 yang terdiri dari 5 siwa laki-laki dan 5 siswa perempuan.

Desain dalam penelitian ini memberikan gambaran secara apa adanya sesuai yang terjadi di lapangan. Secara sistematis proses penentuan subjek dalam penelitian dilakukan dengan langkah-langkah sebagai berikut. (1) memberi tes kepada siswa untuk mengetahui kesalahan siswa; (2) mengelompokkan siswa berdasarkan data hasil tes dengan indikator kesalahan menurut Newman; (3) memilih subjek dari perwakilan gender siswa yang berjumlah 1 orang untuk melakukan wawancara sesuai dengan indikator kesalahan menurut Newman; (4) melakukan wawancara kepada siswa untuk mengetahui kesalahan yang dilakukan dalam menyelesaikan soal; (4) menganalisis data dari hasil pekerjaan siswa dan menarik kesimpulan dari data yang dikumpulkan

Soal yang diujikan kepada siswa dalam penelitian ini yaitu soal materi himpunan kelas VII yang berjumlah 4 butir dan telah divalidasi oleh 1 orang ahli. Validasi dilakukan terhadap instrumen tes dan terhadap panduan wawancara. Hasil validasi menunjukkan bahwa instrumen tersebut memenuhi kriteria valid. Dengan demeikian, kedua instrumen tersebut dapat dijadikan sebagai instrumen penelitian dalam penelitian ini.

Triangulasi dalam pengujian kredibilitas diartikan sebagai pemeriksaan data dari berbagai sumber dengan berbagai cara dan waktu (Sugiyono, 2017). Triangulasi metode merupakan pengecekan keabsahan data yang digunakan dalam penelitian ini yaitu dengan membandingkan data hasil tes dan data hasil wawancara.

Instrumen utama dalam penelitian ini adalah peneliti itu sendiri, hal ini sesuai dengan yang dikemukakan oleh (Evianti et al., 2019) bahwa yang menjadi instrumen (pengumpul data) adalah peneliti itu sendiri. Penelitian kualitatif sebagai human instrument digunakan untuk menentukan tujuan penelitian, memilih informan sebagai sumber data, melakukan pengumpulan data, mengevaluasi kualitas data, menganalisis data, menginterpretasikan data, dan menarik kesimpulan tentang temuan. Peneliti juga menggunakan instrumen pendukung lainnya, yaitu: soal tes dan pedoman wawancara. Dengan pemilihan partisipan siswa kelas VII yang berjumlah 10 siswa dan pemilihan partisipan tersebut dilakukan secara sukarela dikarenakan kondisi pandemi seperti saat ini. Berikut soal tes yang digunakan sebagai instrumen dalam penelitian ini.

1. Dari sekelompok olahragawan, terdapat 18 olahragawan bulu tangkis, 16 olahragawan bola basket, dan12 olahragawan kedua-duanya. Tentukan jumlah olahragawan tersebut! Gambarlah diagram Vennnya! 
2. Dari 50 siswa di suatu kelas, diketahui 25 siswa gemar Matematika, 20 siswa gemar IPA dan 7 siswa gemar kedua-duanya. Tentukan banyak siswa yang tidak gemar Matematika dan IPA! Gambarlah diagram Vennnya!

3. Di antara sekelompok warga yang terdiri atas 50 orang sedang berbelanja ke pasar, ternyata 25 orang membeli buah apel, 10 orang membeli buah pisang dan apel, dan 8 orang tidak membeli kedua macam buah tersebut. Tentukan berapa banyak warga yang membeli buah Pisang saja! Gambarlah diagram Vennnya!

4. Dari 50 siswa, 20 siswa senang berolahraga Voli, 25 siswa senang berolahraga Basket, dan 10 siswa tidak senang keduanya.Tentukan banyak siswa yang senang berolahraga Voli dan Basket! Gambarlah diagram vennnya !

5. Di antara sekelompok warga yang terdiri atas 50 orang sedang berbelanja ke pasar, ternyata 25 orang membeli buah apel, 10 orang membeli buah pisang dan apel, dan 8 orang tidak membeli kedua macam buah tersebut. Tentukan berapa banyak warga yang membeli buah Pisang! Gambarlah diagram Vennnya!

Untuk menganalisis data yang diperoleh dari hasil tes dan wawancara, kemudian menggunakan teknik analisis data sebagai berikut: 1) Reduksi data, dengan mengoreksi jawaban siswa untuk mengetahui jenis-jenis kesalahan, kemudian mengelompokkan jenisjenis kesalahan tersebut menurut kesamaan kesalahan; (2) Representasi data dilakukan dengan mengumpulkan informasi kesalahan masing-masing siswa dari hasil penelitian yang disusun; (3) Verifikasi data dan penarikan kesimpulan yang dilakukan dalam kegiatan analisis untuk mendapatkan kesimpulan akhir. Tujuannya adalah untuk menguji kebenaran kesimpulan yang diambil dan relevansi serta konsistensi judul, tujuan, dan pertanyaan yang diajukan.

Untuk mengetahui persentase setiap jenis kesalahan digunakan rumus sebagai berikut:

$$
P=\frac{\sum S}{\sum B+\sum S} \times 100 \%
$$

Keterangan:

$\mathrm{P}=$ Persentase kesalahan yang dicari

$\Sigma \mathrm{S}=$ Total jawaban salahan dari tipe jenis kesalahan seluruh soal

$\Sigma \mathrm{B}=$ Total jawaban benar dari tiap jenis kesalahan seluruh soal

(Nisa \& Rejeki, 2017) 
Pedoman penskoran yang digunakan dalam penelitian ini yaitu:

Tabel 1. Pedoman Penskoran Menurut Newman

\begin{tabular}{|c|c|c|}
\hline Aspek & Reaksi terhadap soal & Skor \\
\hline \multirow[t]{3}{*}{ Reading error } & $\begin{array}{l}\text { Tidak ada jawaban sama sekali pada lembar } \\
\text { jawaban }\end{array}$ & 0 \\
\hline & $\begin{array}{l}\text { Menuliskan informasi dan yang diketahui tetapi } \\
\text { salah }\end{array}$ & 1 \\
\hline & $\begin{array}{l}\text { Menuliskan informasi dan yang diketahui sesuai } \\
\text { dengan soal }\end{array}$ & 2 \\
\hline \multirow[t]{4}{*}{ Comprehension error } & Tidak ada jawaban sama sekali & 0 \\
\hline & Menuliskan apa yang ditanya tetapi salah & 1 \\
\hline & Menuliskan apa yang ditanya sesuai dengan & 2 \\
\hline & keinginan soal & \\
\hline \multirow[t]{5}{*}{ Tranformation error } & $\begin{array}{l}\text { Tidak menuliskan rumus yang digunakan untuk } \\
\text { menyelesaikan soal }\end{array}$ & 0 \\
\hline & $\begin{array}{l}\text { Menuliskan rumus yang digunakan tapi belum } \\
\text { tepat }\end{array}$ & 1 \\
\hline & $\begin{array}{l}\text { Menuliskan rumus dengan tepat tetapi masih salah } \\
\text { dalam merubah bentuk soal }\end{array}$ & 2 \\
\hline & $\begin{array}{l}\text { Menuliskan rumus dengan tepat dan dapat } \\
\text { merubah bentuk soal dan memasukkannya }\end{array}$ & 3 \\
\hline & kedalam rumus & \\
\hline \multirow[t]{7}{*}{ Process skill error } & Tidak menuliskan proses dalam mengerjakan soal & 0 \\
\hline & Menuliskan proses dalam mengerjakan soal tetapi & 1 \\
\hline & kurang tepat & \\
\hline & Menuliskan proses dalam mengerjakan soal & \\
\hline & dengan tepat tetapi langkah-langkah penyelesaian & 2 \\
\hline & kurang tepat & \\
\hline & $\begin{array}{l}\text { Menuliskan proses dalam mengerjakan soal } \\
\text { dengan tepat dan langkah-langkah penyelesaian }\end{array}$ & 3 \\
\hline
\end{tabular}


dengan baik

Tidak ada jawaban akhir sama skali

Encoding error

ada jawaban akhir tapi salah

Dapat menentukan jawaban akhir dengan benar

2

\section{HASIL PENELITIAN DAN PEMBAHASAN}

Soal tes yang diberikan kepada siswa terdiri dari 4 butir yang berhubungan dengan masalah himpunan. Dibawah ini disajikan tabel data hasil tes yang dikerjakan oleh siswa beserta soal tesnya.

\section{Soal Tes}

1. Dari sekelompok olahragawan, terdapat 18 olahragawan bulu tangkis, 16 olahragawan bola basket, dan12 olahragawan kedua-duanya. Tentukan jumlah olahragawan tersebut! Gambarlah diagram Vennnya!

2. Dari 50 siswa di suatu kelas, diketahui 25 siswa gemar Matematika, 20 siswa gemar IPA dan 7 siswa gemar kedua-duanya. Tentukan banyak siswa yang tidak gemar Matematika dan IPA! Gambarlah diagram Vennnya!

3. Di antara sekelompok warga yang terdiri atas 50 orang sedang berbelanja ke pasar, ternyata 25 orang membeli buah apel, 10 orang membeli buah pisang dan apel, dan 8 orang tidak membeli kedua macam buah tersebut. Tentukan berapa banyak warga yang membeli buah Pisang saja! Gambarlah diagram Vennnya!

4. Dari 50 siswa, 20 siswa senang berolahraga Voli, 25 siswa senang berolahraga Basket, dan 10 siswa tidak senang keduanya.Tentukan banyak siswa yang senang berolahraga Voli dan Basket! Gambarlah diagram vennnya !

5. Di antara sekelompok warga yang terdiri atas 50 orang sedang berbelanja ke pasar, ternyata 25 orang membeli buah apel, 10 orang membeli buah pisang dan apel, dan 8 orang tidak membeli kedua macam buah tersebut. Tentukan berapa banyak warga yang membeli buah Pisang! Gambarlah diagram Vennnya. 
Tabel 2. Deskripsi Hasil Pekerjaan Siswa

\begin{tabular}{|c|c|c|c|c|c|c|c|c|c|c|}
\hline \multicolumn{11}{|c|}{ Jenis Kesalahan } \\
\hline \multirow{2}{*}{ Butir Soal } & \multicolumn{2}{|c|}{ Reading } & \multicolumn{2}{|c|}{ Comprehension } & \multicolumn{2}{|c|}{ Transformation } & \multicolumn{2}{|c|}{ Process Skill } & \multicolumn{2}{|c|}{ Encoding } \\
\hline & $\sum B$ & $\sum S$ & $\sum B$ & $\sum S$ & $\sum B$ & $\sum S$ & $\sum B$ & $\sum S$ & $\sum B$ & $\sum S$ \\
\hline 1. & 7 & 3 & 2 & 8 & 2 & 8 & 2 & 8 & 2 & 8 \\
\hline 2. & 7 & 3 & 1 & 9 & 1 & 9 & 1 & 9 & 1 & 9 \\
\hline 3. & 6 & 4 & 1 & 9 & 1 & 9 & 1 & 9 & 1 & 9 \\
\hline 4. & 5 & 5 & 1 & 9 & 1 & 9 & 1 & 9 & 1 & 9 \\
\hline Total & 25 & 15 & 5 & 35 & 5 & 35 & 5 & 35 & 5 & 35 \\
\hline Persentase & \multicolumn{2}{|c|}{$37,5 \%$} & \multicolumn{2}{|c|}{$87,5 \%$} & \multicolumn{2}{|c|}{$87,5 \%$} & \multicolumn{2}{|c|}{$87,5 \%$} & \multicolumn{2}{|c|}{$87,5 \%$} \\
\hline
\end{tabular}

Berdasarkan Tabel 2 di atas, diketahui persentase kesalahan siswa dalam menyelesaikan masalah himpunan yaitu Reading error 37,5\%, Comprehension error 87,5\%, Transformation error 87,5\%, Process skill error 87,5\%, dan Encoding error $87,5 \%$.

Kemudian setelah dilakukannya kegiatan tes dan wawancara didapatkan data hasil analisis kesalahan, akan dideskripsikan kesalahan yang dilakukan siswa dalam menyelesaikan masalah himpunan.

1. Reading Error (Kesalahan Membaca)

Reading Error yaitu kesalahan yang dilakukan siswa pada saat membaca soal, siswa dapat membaca kata kunci atau simbol yang terdapat pada soal. Dari analisis data yang telah di peroleh, Reading Error dari seluruh soal yaitu 15. Persentase dalam Reading Error yaitu 37,5\%. Sebagian besar siswa telah membaca soal dengan baik, hanya saja masih ada siswa yang kurang lengkap dan tidak mencantum informasi dalam soal.Reading Error yang dilakukan dalam penelitian ini sesuai dengan penelitian yang dilakukan oleh (Susanti, 2019) yaitu siswa tidak mampu membaca soal dan tidak mampu menulis informasi yang terdapat dalam soal. Contoh kesalahan membaca adalah kesalahan yang dilakukan oleh subjek 7 (S-7) pada saat mengerjakan soal no. 2. Contoh kesalahan tersebut dapat dilihat sebagai berikut. 


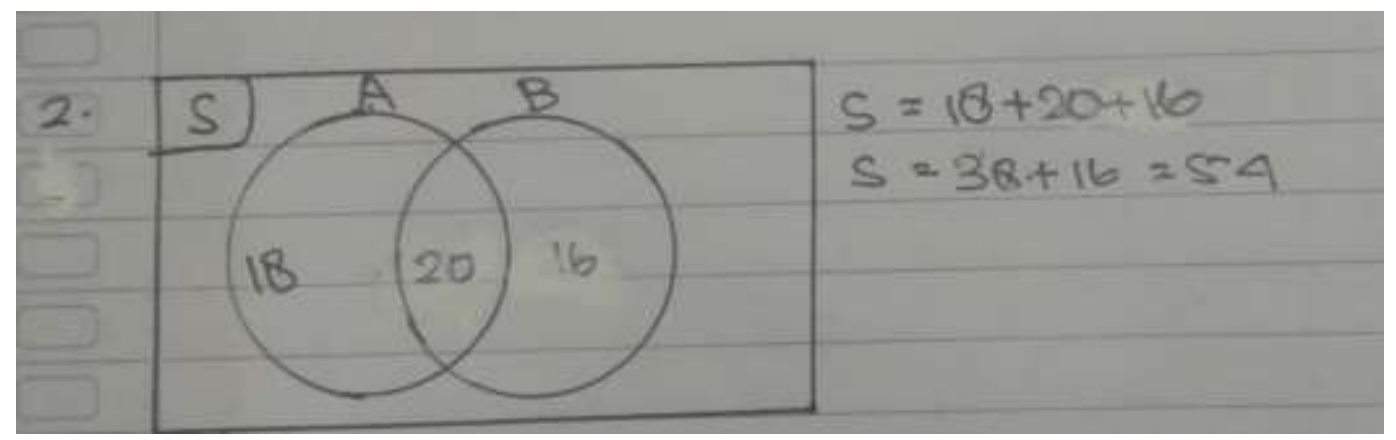

Gambar 2. Kesalahan Reading

Berdasarkan Gambar 2 di atas S-7 tidak menuliskan informasi dari soal akan tetapi langsung pada proses pengerjaan.Berdasarkan data analisishasil wawancara S-7, kesalahan dalam Reading dikarenakan S-7 tidak terbiasa dengan menuliskan diketahui dalam menjawab soal. Triangulasi dari hasil wawancara dan hasil tes adalah S-7 tidak terbiasa untuk menuliskan apa yang diketahui dalam menjawab soal sehingga dalam mengerjakan soal S-7 mengalami kesulitan dikarenakan tidak mengetahui informasi apa yang ada di dalam soal. Hal ini berarti S-7 melakukan kesalahan dalam membaca soal (reading error)

\section{Comprehension Error (Kesalahan Pemahaman)}

Comprehension Error yaitu kesalahan yang dilakukan siswa dalam memahami pertanyaan soal, siswa tidak dapat menemukan informasi yang terdapat dalam soal, sehingga siswa melakukan kesalahan dalam proses selanjutnya. Dari analisis data yang diperoleh, Comprehension Error dari seluruh soal yaitu 35. Persentase dalam Comprehension Error yaitu 87,5\%. Masih banyak siswa yang tidak memahami apa yang ditanyakan dalam soal dan tidak dapat menemukan informasi yang terdapat dalam soal.Comprehension Error yang dilakukan dalam penelitian ini sesuai dengan penelitian yang dilakukan oleh (Mahmudah, 2018) yaitu masih banyak siswa yang tidak memahami dan tidak menuliskan apa yang ditanya dalam soal.Contoh kesalahan memahami soal adalah kesalahan yang dilakukan oleh subjek 8 (S-8) pada saat mengerjakan soal no. 1. Contoh kesalahan tersebut dapat dilihat sebagai berikut. 


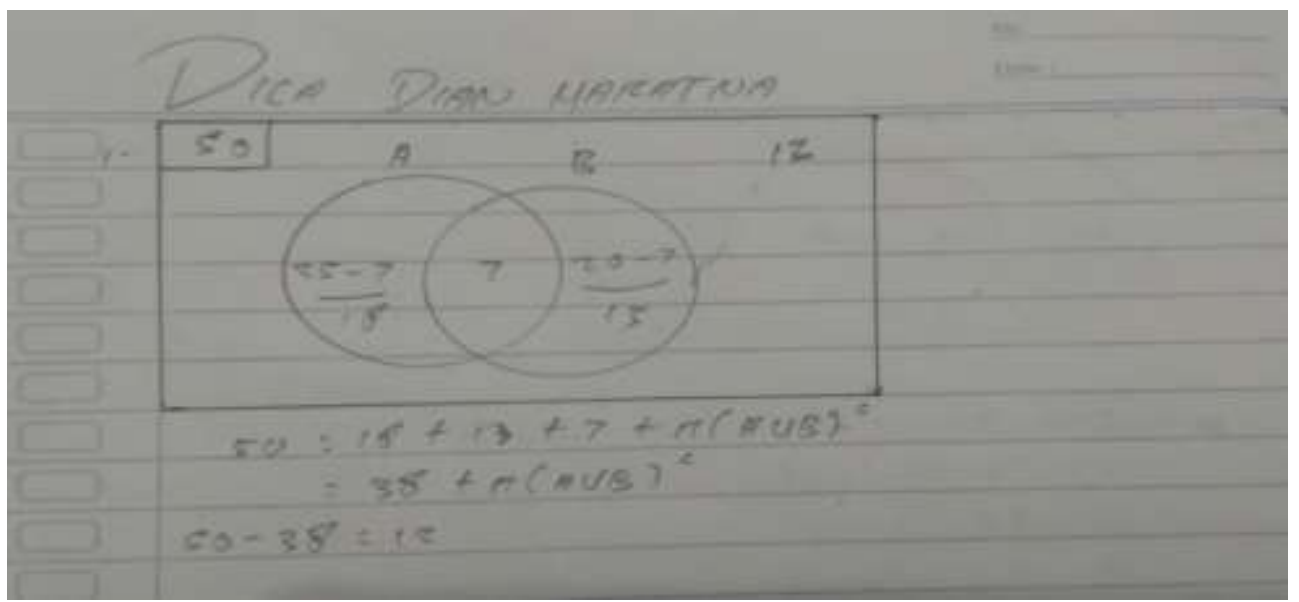

Gambar 3. Kesalahan Comprehension

Berdasarkan Gambar 3 di atas S-8 tidak menuliskan informasi dan apa yang ditanyakan di dalam soal akan tetapi langsung pada proses pengerjaan. Berdasarkan hasil dari analisis data wawancara, S-8 tidak memahami apa yang ditanya dalam soal dan tidak terbiasa menuliskan apa yang ditanya saat menjawab soal.

Triangulasi dari hasil wawancara dan hasil tes adalah S-8 tidak terbiasa untuk menuliskan apa yang tanyakan dalam menjawab soal sehingga dalam mengerjakan soal S-8 mengalami kesulitan dikarenakan tidak mengetahui apa yang inginkan oleh soal. Hal ini berarti S-8 melakukan kesalahan dalam memahami soal (comprehension error)

\section{Transformation Error (Kesalahan Transformasi)}

Transformation Error yaitu kesalahan yang dilakukan oleh siswa dalam mengubah soal kedalam bentuk matematika. Dari analisis data yang telah diperoleh, Transformation Error dari seluruh soal yaitu 35. Persentase dalam Tranformation Error yaitu $87,5 \%$. Masih banyak siswa yang salah dan tidak bisa mengubah soal keadalam bentuk matematika.Transformation Error dalam penelitian ini sesuai dengan penelitian yang dilakukan oleh (Mulyani \& Muhtadi, 2019) yaitu siswa tidak bisa dalam mengubah soal kedalam bentuk matematika. Contoh kesalahan dalam mentransformasi soal adalah kesalahan yang dilakukan oleh subjek 3 (S-3) pada saat mengerjakan soal no. 4. Contoh kesalahan tersebut dapat dilihat sebagai berikut. 


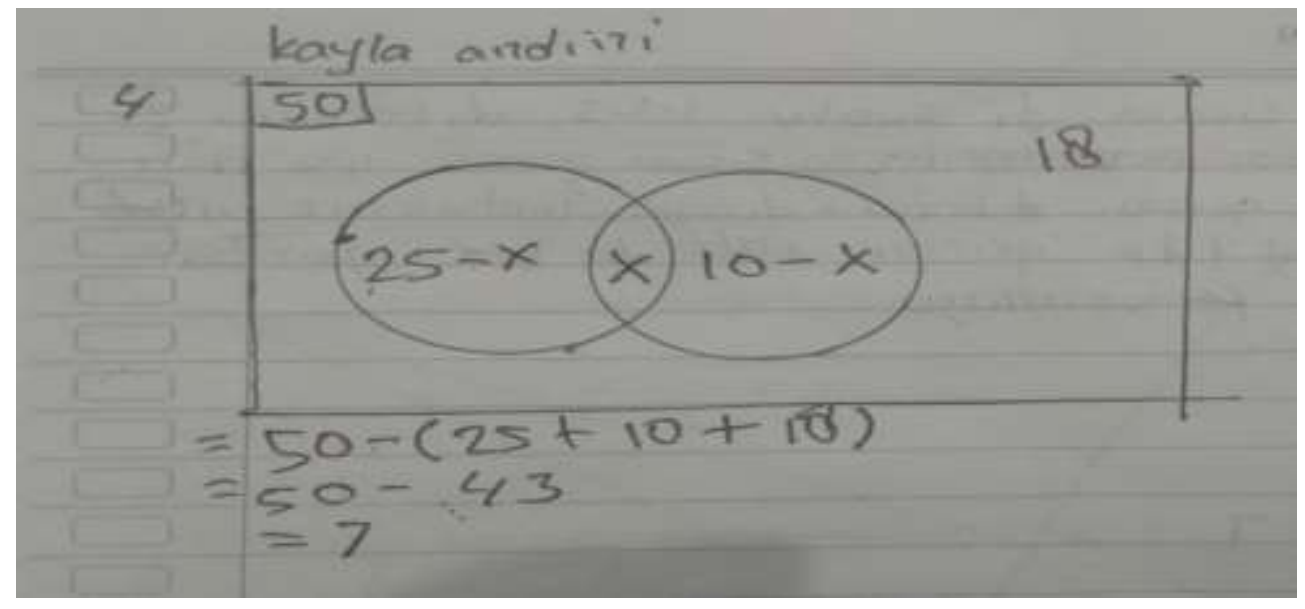

\section{Gambar 4. Kesalahan Tranformation}

Berdasarkan Gambar 4 di atas, S-3 tidak bisa mengubah soal kedalam bentuk matematika akan tetapi langsung memasukan nilai dari informasi yang terdapat dalam soal. Berdasarkan hasil dari analisis data wawancara, S-3 masih belum terbiasa untuk menuliskan simbol-simbol matematika dan masih kurang paham dalam mengubah soal kedalam bentuk matematika.

Triangulasi dari hasil wawancara dan hasil tes adalah S-3 tidak terbiasa untuk mengubah soal kedalam bentuk matematika hal tersebut menyebabkan S-3 mengalami kesulitan dalam menyelesaikan soal dikarenakan tidak dapat mengubah soal tersebut sesuai dengan apa yang di maksud oleh soal dalam bentuk matematika. Hal ini berarti S-3 melakukan kesalahan dalam mengubah bentuk soal (Tranformation error)

\section{Process Skill Error (Kesalahan Proses)}

Process Skill Error yaitu kesalahan yang dilakukan oleh siswa dalam melakukan langkah-langkah menjawab soal. Dari analisis data yang diperoleh, Process Skill Error dari seluruh soal yang dikerjakan siswa yaitu 35. Persentase dalam Process Skill Error yaitu $87,5 \%$. Siswa masih kurang memahami langkah-langkah dalam menyelesaikan soal dan tergesa-gesa dalam menjawab soal. Process Skill Error dalam penelitian ini sesuai dengan penelitian yang telah dilakukan oleh (Sunardiningsih et al., 2019)bahwa siswa tidak dapat memahami langkah-langkah dalam menyelesaikan soal. Contoh kesalahan dalam proses adalah kesalahan yang dilakukan oleh subjek 5 (S-5) pada saat mengerjakan soal no. 3. Contoh kesalahan tersebut dapat dilihat sebagai berikut. 


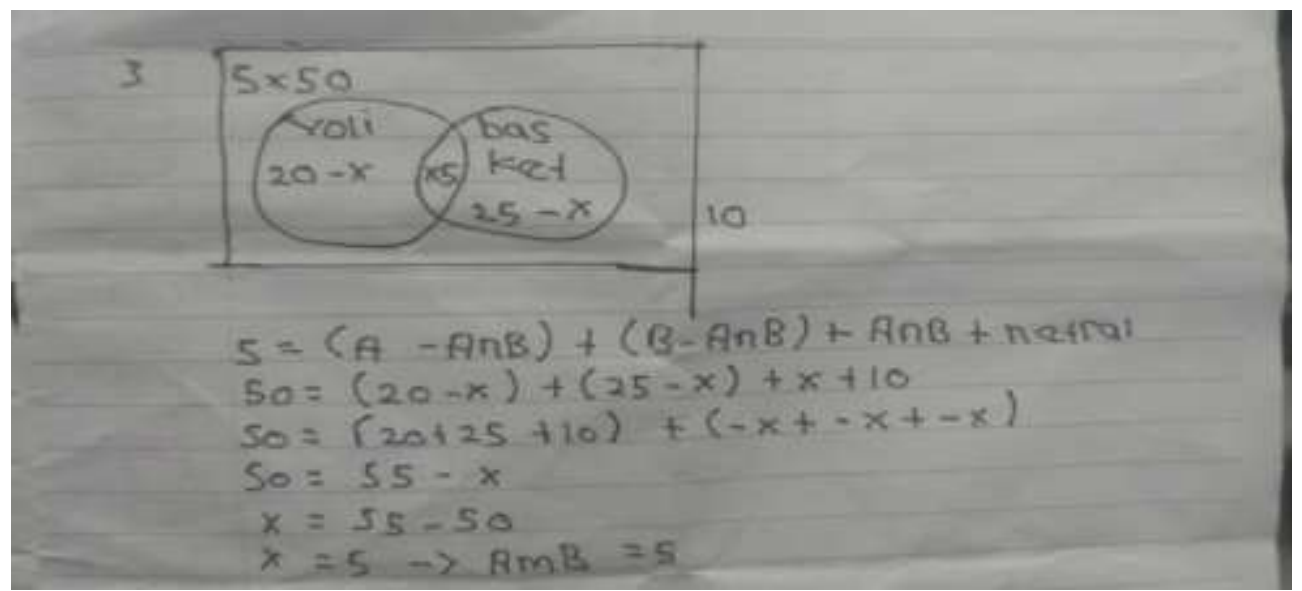

\section{Gambar 5. Kesalahan Process Skill}

Berdasarkan Gambar 5 di atas, S-5 tergesa-gesa dalam menjawab soal dan tidak menuliskan informasi-informasi dalam soal dan melewati langkah-langkah sebelumnya dalam menjawab soal.Dari hasil analisis data wawancara, kurangnya pemahaman dan keterampilan menghitung S-5 sehingga terjadi Process Skill Error

Triangulasi dari hasil wawancara dan hasil tes adalah S-5 melawatkan langkahlangkah sebelumnya dalam menjawab soal tersebut serta informasi yang terdapat dalam soal tidak paparkan dengan jelas sehingga S-5 mengalami kesulitan untuk menentukan penyelesaian dalam soal tersebut. Hal ini berarti S-5 melakukan kesalahan dalam proses (Process sklill error)

\section{Encoding Error (Kesalahan Penulisan Jawaban Akhir)}

Encoding Error merupakan kesalahan yang dilakukan oleh siswa dalam menuliskan jawaban akhir dan tidak dapat menyimpulkan jawaban akhir sesuai dengan kalimat matematika. Dari analisis data yang diperoleh, Encoding Error dari seluruh soal yang dikerjakan siswa yaitu 35. Persentase dari Encoding Error yaitu 87,5\%. Sebagian besar siswa salah dalam menuliskan jawaban akhir dan dalam menuliskan jawaban kedalam bentuk kalimat matematia.Encoding Error dalam penelitian ini sesuai dengan penelitian yang telah dilakukan oleh (Wati \& Murtiyasa, 2016) bahwa kemampuan siswa yang rendah pada penulisan jawaban akhir dalam mengerjakan soal. Contoh kesalahan dalam menuliskan jawaban akhir adalah kesalahan yang dilakukan oleh subjek 1 (S-1) pada saat mengerjakan soal no. 4. Contoh kesalahan tersebut dapat dilihat sebagai berikut. 


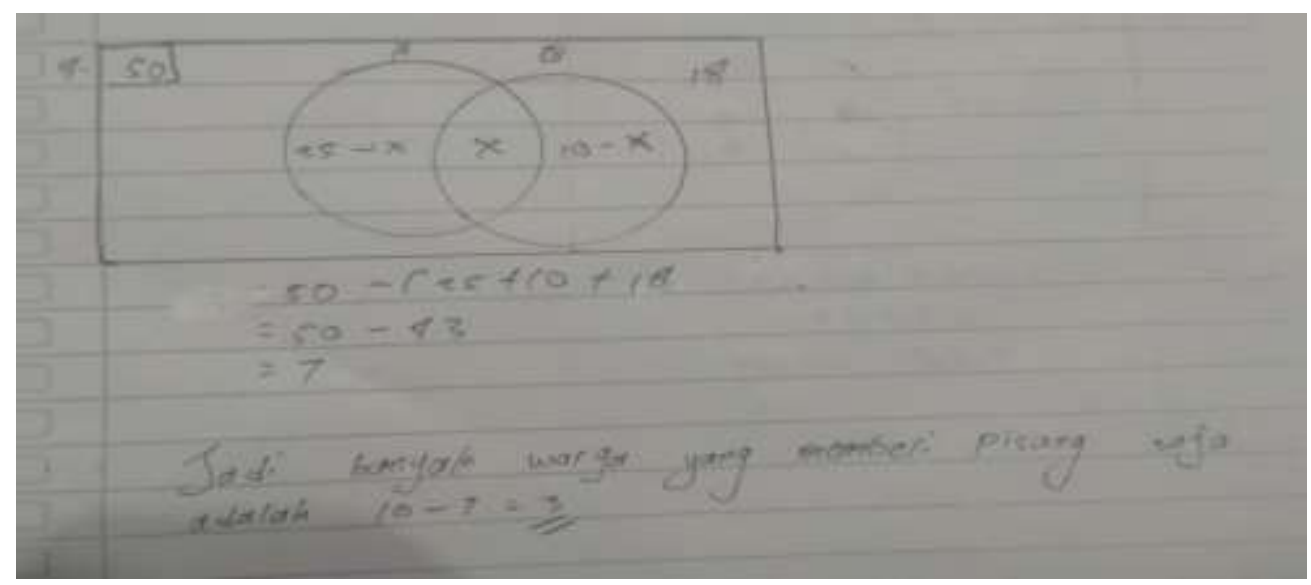

\section{Gambar 6. Kesalahan Encoding}

Berdasarkan Gambar 6 di atas, S-1 masih salah dalam menentukan solusi dari soal sehingga menyebabkan kesalahan dalam jawaban akhir. Berdasarkan hasil analisis data wawancara, S-1 masih kurang memahami materi dari soal yang diberikan sehingga terjadi kesalahan pada jawaban akhir dari pekerjaan

Triangulasi dari hasil wawancara dan hasil tes adalah S-1 melakukan kesalahan dalam menentukan solusi dalam soal sehingga S-1 mengalami kesulitan untuk menentukan jawaban akhir dengan tepat. Hal ini berarti S-1 melakukan kesalahan dalam menuliskan jawaban akhir (encoding error)

Untuk kesalahan yang dilakukan oleh subjek penelitian yang lain sebagian besar kesalahan yang dilakukan dalam menyelesaikan soal masih sama dengan kesalahan yang dilakukan oleh subjek-subjek sebelumnya dalam menyelesaikan soal yang diberikan oleh peneliti. Selanjutnya akan dibedakan data kesalahan hasil pekerjaan siswa laki-laki dan siswa perempuan dalam menyelesaikan masalah himpunan yang terdiri dari 4 butir soal. Dibawah ini disajikan tabel data hasil tes siswa laki-laki dan perempuan.

\section{Tabel 3. Deskripsi Data Hasil Perkerjaan Siswa Laki-Laki}

\begin{tabular}{|c|c|c|c|c|c|c|c|c|c|c|}
\hline \multicolumn{11}{|c|}{ Jenis Kesalahan } \\
\hline \multirow{2}{*}{ Butir Soal } & \multicolumn{2}{|c|}{ Reading } & \multicolumn{2}{|c|}{ Comprehension } & \multicolumn{2}{|c|}{ Transformation } & \multicolumn{2}{|c|}{ Process Skill } & \multicolumn{2}{|c|}{ Encoding } \\
\hline & $\sum B$ & $\sum S$ & $\sum B$ & $\sum S$ & $\sum B$ & $\sum S$ & $\sum B$ & $\sum S$ & $\sum B$ & $\sum S$ \\
\hline 1. & 2 & 3 & 1 & 4 & 1 & 4 & 1 & 4 & 1 & 4 \\
\hline 2. & 2 & 3 & 1 & 4 & 1 & 4 & 1 & 4 & 1 & 4 \\
\hline 3. & 1 & 4 & 1 & 4 & 1 & 4 & 1 & 4 & 1 & 4 \\
\hline 4. & 1 & 4 & 1 & 4 & 1 & 4 & 1 & 4 & 1 & 4 \\
\hline Total & 6 & 14 & 4 & 16 & 4 & 16 & 4 & 16 & 4 & 16 \\
\hline Persentase & \multicolumn{2}{|c|}{$70 \%$} & \multicolumn{2}{|c|}{$80 \%$} & \multicolumn{2}{|c|}{$80 \%$} & \multicolumn{2}{|c|}{$80 \%$} & \multicolumn{2}{|c|}{$80 \%$} \\
\hline
\end{tabular}


Berdasarkan Tabel 3 di atas, diketahui persentase kesalahan siswa laki-laki dalam menyelesaikan masalah himpunan yaitu Reading error 70\%, Comprehension error $80 \%$, Transformation error $80 \%$, Process skill error $80 \%$, dan Encoding error $80 \%$.

Tabel 4. Deskripsi Hasil Pekerjaan Siswa Perempuan

\begin{tabular}{|c|c|c|c|c|c|c|c|c|c|c|}
\hline \multicolumn{11}{|c|}{ Jenis Kesalahan } \\
\hline \multirow{2}{*}{ Butir Soal } & \multicolumn{2}{|c|}{ Reading } & \multicolumn{2}{|c|}{ Comprehension } & \multicolumn{2}{|c|}{ Transformation } & \multicolumn{2}{|c|}{ Process Skill } & \multicolumn{2}{|c|}{ Encoding } \\
\hline & $\sum B$ & $\sum S$ & $\sum B$ & $\sum S$ & $\sum B$ & $\sum S$ & $\sum B$ & $\sum S$ & $\sum B$ & $\sum S$ \\
\hline 1. & 5 & 0 & 1 & 4 & 1 & 4 & 1 & 4 & 1 & 4 \\
\hline 2. & 5 & 0 & 0 & 5 & 0 & 5 & 0 & 5 & 0 & 5 \\
\hline 3. & 5 & 0 & 0 & 5 & 0 & 5 & 0 & 5 & 0 & 5 \\
\hline 4. & 4 & 1 & 0 & 5 & 0 & 5 & 0 & 5 & 0 & 5 \\
\hline Total & 19 & 1 & 1 & 19 & 1 & 19 & 1 & 19 & 1 & 19 \\
\hline Persentase & \multicolumn{2}{|c|}{$5 \%$} & \multicolumn{2}{|c|}{$95 \%$} & \multicolumn{2}{|c|}{$95 \%$} & \multicolumn{2}{|c|}{$95 \%$} & \multicolumn{2}{|c|}{$95 \%$} \\
\hline
\end{tabular}

Berdasarkan Tabel 4 di atas, diketahui persentase kesalahan siswa perempuan dalam menyelesaikan masalah himpunan yaitu kesalahan dalam membaca soal (Reading error) sebesar5\%, kesalahan dalam memahami soal (Comprehension error) sebesar95\%, kesalahan dalam mengubah soal (Transformation error) sebesar95\%, kesalahan dalam proses (Process skill error) sebesar 95\%, dan kesalahan dalam menuliskan jawaban akhir (Encoding error) sebesar $95 \%$.

Selanjutnya disajikan dua hasil wawancara yang diberikan kepada masing-masing satu perwakilan siswa berdasarkan gender yang dilakukan oleh peneliti (P) yaitu sebagai berikut.

1. Hasil wawancara S-5 (siswa laki-laki)

P : “coba bacakan soal no.1)

S-5 : "(membaca dalam hati)"

P : "apa yang kamu ketahui dalam soal no.1.?"

S-5 : “ jumlah olahragawan bulu tangkis 18 orang, 16 olahragawan bola basker dan 12 olahragawan keduanya."

P :'kenapa kamu tidak menulisnya di jawabanmu.?"

S-5 : "saya kurang terbiasa menulisnya kak"

P : "lain kali harus ditulis ya, selanjutnya apa yang ditanya dalam soal.?"

S-5 ; "(terdiam sambil berpikir)"

P ; "kamu tidak tau.?"

S-5 : “ jumalah keseluruhan olahrgawan” 
P : " nah kenapa tidak dituliskan juga apa yang ditanya.?"

S-5 : "lupa pak."

P : "Simbol jumlah keseluruhan olahragawan apa"

S-5 : "S pak"

P : "simbol jumlah olahragawan yang suka basket dan bulutangkis apa ?

S-5 : "tidak tau pak"

P : A $\cap B$, dipelajari lagi ya, selanjutnya apa rumus dari menentukan nilai S.?”

S-5 : "lupa pak “

P : "kenapa langsung menulis langkahnya seperti ini kalau lupa .?"

S-5 : “(diam)”

Dari hasil wawancara tersebut S-5 masih banyak melakukan kesalahan dalam menyelesaiakan soal antara lain kesalahan saat membaca soal (reading error), kesalahan saat memahami soal (comprehension error), kesalahan dalam mengubah soal (transformation error), kesalahan dalam proses ( process skill error), dan kesalahan dalam menuliskan jawaban akhir (encoding error). Hal ini yang menyebabkan S-5 mengalami kesulitan saat menyelesaikan soal yang diberikan.

2. Hasil wawancara S-7 (siswa perempuan)

P : “ apa yang kamu ketahui dari soal no 2.?"

S-1 : “(membaca soal) jumlah siswa gemar matematika 25, gemar IPA 20 dan gemar keduanya 7 "

P : "kenapa tidak dituliskan di jawaban terlebih dahulu.?"

S-1 : "lupa pak"

P : "apa yang ditanyakan dalam soal tersebut .?"

S-1 : " jumlah keseluruhan pak"

P : apa simbolnya.?"

S-1 : "S pak"

P : "simbol dari gemar keduanya dalam bentuk matematika bagaimana.?"

S-1 : " tidak tau pak"

P : "lalu kenapa kamu langsung mengisi jawaban kamu tanpa menggunakan rumus yang telah diajarkan.?”

S-1 : "saya tergesa-gesa pak karena takut kehabisan waktu" 
Dari hasil wawancara tersebut S-1 masih banyak melakukan kesalahan dalam menyelesaiakan soal sama seperti subjek wawancara sebelumnya antara lain kesalahan dalam membaca soal (reading error), kesalahan dalam memahami soal (comprehension error), kesalahan dalam mengubah soal (transformation error), kesalahan dalam proses ( process skill error), dan kesalahan dalam menuliskan jawaban akhir (encoding error). Hal ini yang menyebabkan S-1 kesulitan dalam menyelesaikan soal yang diberikan.

Dari penyajian kedua Tabel deskripsi data hasil pekerjaan siswa dan hasil wawancara tersebut, tidak ada perbedaan kesalahan yang mencolok antara siswa laki-laki dan siswa perempuan dalam menyelesaikan masalah himpunan. Data hasil tes dan wawancara siswa laki-laki dalam menyelesaikan masalah pada soal tes himpunan menunjukkan masih rendahnya kemampuan siswa dalam membaca dan menentukan informasi dari soal, kemampuan pemahaman, kemampuan mengubah bentuk soal, kemampuan memahami konsep perhitungan, dan kemampuan dalam penulisan jawaban akhir. Sedangkan untuk data hasil tes dan wawacara siswa perempuan menunjukkan bahwa masih rendahnya kemampuan siswa dalam kemampuan pemahaman, kemampuan mengubah bentuk soal, memahami konsep perhitungan, dan tidak terbiasa dalam penulisan jawaban akhir. Hasil penelitian Ismunandar, kesalahan siswa pada umumnya dalam menyelessaikan soal matematika adalah tidak menuliskan hal - hal yang diketahui dengan lengkap dan kurang paham dengan permasalahan yang disampaikan sehingga berdampak pada proses mengerjakan yang kurang tepat, dengan demikian ini berdampak pada kesalahan di hasil akhir pengerjaan siswa(Ismunandar \& Nurafifah, 2021).

\section{KESIMPULAN}

1. Persentase kesalahan keseluruhan dari hasil tes yang dilakukan oleh siswa yaitu dengan kesalahan membaca (Reading error) 37,5\%, kesalahan pemahaman (Comprehension error) 87,5\%, kesalahan dalam tranformasi soal (Transformation error)87,5\%, kesalahan dalam proses (Process skill error)87,5\%, dan yang terakhir yaitu keasalahan dalam penulisan jawaban akhir (Encoding error)87,5\% Sedangkan kesalahan siswa ditinjau dari prosedur analisis kesalahan newman adalah sebagai berikut. 
a. Kesalahan membaca (reading error)

siswa kurang mampu membaca soal dan tidak menulis informasi yang terdapat dalam soal

b. Kesalahan pemahaman (comprehension error)

Masih banyak siswa yang tidak memahami dan tidak menuliskan apa yang ditanya dalam soal

c. Kesalahan tranformasi (tranformation error) siswa tidak bisa dalam mengubah soal kedalam bentuk matematika

d. Kesalahan proses (process skill error)

Siswa masih tergesa-gesa dalam menjawab soal dan tidak menuliskan informasi-informasi dalam soal dan melewati langkah-langkah sebelumnya dalam menjawab soal

e. Kesalahan penulisan jawaban akhir (encding error)

Siswa masih kurang memahami materi dari soal yang diberikan sehingga terjadi kesalahan dalam jawaban akhir dari pekerjaan

2. Persentase kesalahan untuk siswa laki-lakiyaitu Reading error $70 \%$, Comprehension error $80 \%$, Transformation error $80 \%$, Process skill error $80 \%$, dan Encoding error 80\%. Dimana data hasil tes dan wawancara siswa laki-laki dalam menyelesaikan masalah pada soal tes himpunan menunjikkan masih rendahnya kemampuan siswa dalam membaca dan menentukan informasi dari soal, kemampuan pemahaman, kemampuan mengubah bentuk soal, memahami konsep perhitungan, dan tidak terbiasa dalam penulisan jawaban akhir.

3. Sedangkan persentase kesalahan untuk siswa perempuan yaituReading error 5\%, Comprehension error 95\%, Transformation error 95\%, Process skill error 95\%, dan Encoding error 95\%. Untuk data hasil tes dan wawacara siswa perempuan menunjukkan bahwamasih rendahnya kemampuan siswa dalam kemampuan pemahaman, kemampuan mengubah bentuk soal, memahami konsep perhitungan, dan kesalahan dalam penulisan jawaban akhir.

Berdasarkan hasil dari penelitian dalam menyelesaikan masalah himpunan siswa kelas VII ditinjau dari gender diperoleh kesimpulan bahwa tidak ada perbedaan yang mencolok antara kesalahan siswa laki-laki dan siswa perempuan. Hasil penelitian ini dapat menjadi tambahan ilmu pengetahuan bagi dunia pendidikan, terutama dalam 
menyelesaikan soal himpunan. Siswa masih cenderung melakukan kesalahan dalam membaca soal, memahami informasi yang terdapat dalam soal, menyelesaikan soal sesuai dengan langkah-langkah yang diinginkan oleh soal, dan penulisan jawaban akhir dari soal baik dari siswa laki-laki maupun siswa perempuan. Sehingga dalam mengajar dan menyampaikan materi guru diharapkan lebih menekankan siswa dalam mehami informasiinformasi yang terdapat dalam soal. Penelitian selanjutnya diharapkan agar mengkaji soal matematika dalam materi yang lainnya sehingga dapat mengoptimalkan pemahaman siswa dalam memahami materi yang diberikan.

\section{DAFTAR PUSTAKA}

Aini, K. N. (2017). Proses berpikir mahasiswa laki-laki dan perempuan dengan gaya kognitif field independent dalam memecahkan masalah. Inspiramatika, 3(1), 16-23. Evianti, N., Jafar, J., Busnawir, B., \& Masi, L. (2019). Analisis Kesalahan Siswa Kelas IX MTs Negeri 2 Kendari Dalam Menyelesaikan Soal-Soal Lingkaran. Jurnal Pendidikan Matematika, 10(2), 138. https://doi.org/10.36709/jpm.v10i2.7247 Ismunandar, D., \& Nurafifah, L. (2021). Analisis Kesalahan Mahasiswa pada Bab Tree dan Spanning Tree Berdasarkan Prosedur Newman. JMPM, 6(1), 1-14.

Kamariah. (2018). Analisis Kesalahan Siswa dalam Menyelesaikan Soal Himpunan Berdasarkan Kriteria Watson di Kelas VII MTs Syekh Yusuf Sungguminasa Kabupaten Gowa. UIN Alauddin, Makassar. Skripsi, 1-95.

Mahmudah, W. (2018). Analisis Kesalahan Siswa dalam Menyelesaikan Soal Matematika Bertipe HOTS Berdasar Teori Newman. Jurnal UJMC, 4(1), 49-56.

Mulyani, M., \& Muhtadi, D. (2019). Analisis Kesalahan Siswa Dalam Menyelesaikan Soal Trigonometri Tipe Higher Order Thinking Skill Ditinjau Dari Gender. Jurnal Penelitian Dan Pembelajaran Matematika, 12(1), 1-16.

https://doi.org/10.30870/jppm.v12i1.4851

Munawaroh, N., Rohaeti, E. E., \& Aripin, U. (2018). Analisis Kesalahan Siswa

Berdasarkan Kategori Kesalahan Menurut Watson dalam Menyelesaikan Soal Komunikasi Matematis Siwa SMP. JPMI (Jurnal Pembelajaran Matematika Inovatif), 1(5), 993. https://doi.org/10.22460/jpmi.v1i5.p993-1004

Mustangin, Fathani, A. H., \& Sugiharto, T. (2019). PENERAPAN PROBLEM BASED

LEARNING UNTUK MENINGKATKAN KEMAMPUAN PEMECAHAN MASALAH KONTEKSTUAL BAGI PESERTA DIDIK KELAS X-IPA SMA 
ISLAM HASYIM ASY'ARI BATU PADA MATERI SISTEM PERSAMAAN LINEAR TIGA VARIABEL. Buana Matematika : Jurnal Ilmiah Matematika Dan Pendidikan Matematika, 9, 81-86.

Nisa, M. K., \& Rejeki, S. (2017). Analisis Kesalahan Siswa Kelas VII dalam Memecahkan Soal Matematika Model PISA Konten Quantity. Seminar Nasional Pendidikan Matematika.

Nur Aly, B. F., Sujadi, A. A., \& Taufiq, I. (2019). Analisis Kesalahan dalam Menyelesaikan Soal Matematika pada Siswa Kelas X SMK Negeri 1 Seyegan.

UNION: Jurnal Ilmiah Pendidikan Matematika, 7(1), 135.

https://doi.org/10.30738/union.v7i1.4050

Rahayu, S. (2016). Analisis Kesalahan Siswa Dalam Menyelesaikan Soal-Soal

Kesebangunan. Jurnal E-DuMath, 2(1), 1-9.

Sahriah, S. (2012). Analisis Kesalaahan Siswa dalam Menyelesaiakan Soal Matematika

Materi Operasi Pecahan Bentuk Aljabar Kelas VIII SMP Negeri 2 Malang. Jurnal

Online Universitas Negeri Malang, 1(1), 1-10.

Suciati, I., \& Wahyuni, D. S. (2018). Analisis Kesalahan Siswa Dalam Menyelesaikan Soal Matematika Pada Operasi Hitung Pecahan Pada Siswa Kelas V Sdn Pengawu. Jurnal Penelitian Dan Pembelajaran Matematika, 11(2), 129-144.

https://doi.org/10.30870/jppm.v11i2.3760

Sudiono, E. (2017). Analisis Kesalahan Dalam Menyelesaikan Soal Matematika Materi

Persamaan Garis Lurus Berasarkan Analisis Newman. UNION: Jurnal Ilmiah

Pendidikan Matematika, 5(3), 295-302. https://doi.org/10.30738/.v5i3.1282

Sugiyono. (2017). Metode Penelitian Kuantitatif, Kualitatif, dan R\&D. PT Alfabeta

Bandung.

Sumadiasa, I. G. (2014). Analisis Kesalahan Siswa Kelas VIII SMP Negeri 5 Dolo dalam

Menyelesaikan Soal Luas Permukaan dan Volume Limas. Jurnal Elektronik

Pendidikan Matematika Tadulako, 01(2), 184-207.

Sunardiningsih, G. W., Hariyani, S., \& Fayeldi, T. (2019). Analisis Kesalahan Siswa

Dalam Menyelesaikan Soal Matematika Berdasarkan Analisis Newman. Jurnal Terapan Sains \& Teknologi (RAINSTEK), 1(2), 41-45.

Susanti, S. (2019). Newman Procedure dalam Menganalisis Kesalahan Siswa SMP dalam Menyelesaikan Soal Setara PISA. Edumatika: Jurnal Riset Pendidikan Matematika. https://doi.org/10.32939/ejrpm.v2i1.283

Timutius, F., Apriliani, N. R., \& Bernard, M. (2018). Analisis Kesalahan Siswa Kelas Ix-G 
54 Analisis Kesalahan Dalam Menyelesaikan Masalah Himpunan Siswa SMP Kelas VII Ditinjau Dari Gender

Di Smp Negeri 3 Cimahi Dalam Menyelesaikan Soal Pemecahan Masalah Matematik Pada Materi Lingkaran. JPMI (Jurnal Pembelajaran Matematika Inovatif), 1(3), 305. https://doi.org/10.22460/jpmi.v1i3.p305-312

Ulifa, S. N., \& Effendy, D. (2019). Analisis Kesalahan Siswa Dalam Menyelesaikan Soal Matematika Pada Materi Relasi. Jurnal Pendidikan Matematika STKIP PGRI Sidoarjo, 53(9), 1689-1699.

Wahyuni, V., Moralita, G., Effendi, F., \& Yenni. (2019). SOAL MATEMATIKA KELAS VIII MODEL PISA KONTEN CHANGE AND RELATIONSHIP BERDASARKAN PROSEDUR. 4, 114-127.

Wati, E. H., \& Murtiyasa, B. (2016). Kesalahan siswa SMP dalam menyelesaikan soal matematika berbasis PISA pada konten change and relationship. Konferensi Nasional Penelitian Matematika Dan Pembelajarannya (KNPMP I). 